\title{
ANALISIS SEKTOR STRATEGIS PULAU SULAWESI, JAWA TIMUR DAN KALIMANTAN TIMUR
}

\author{
Arman, Setia Hadi, Noer Azam Achsani, dan Akhmad Fauzi \\ Program Studi Agribisnis, Fakultas Bioindustri Universitas Trilogi \\ E-mail: arman@universitas-trilogi.ac.id
}

\begin{abstract}
ABSTRAK. Penelitian ini menganalisis sektor-sektor strategis, responsif sektor, sektor sensitif dan sektor untuk tumbuh dengan baik di daerah lain Sulawesi (Sulawesi Utara, Sulawesi Tengah, Sulawesi Tenggara dan Gorontalo), Sulawesi Selatan (termasuk South West), Jawa Timur dan Kalimantan Timur. Temukan locationbased pada intensitas interaksi perdagangan antar daerah ada characteristicof andthe ekonomi masing-masing daerah. Sektor strategis adalah sektor yang mendukung kinerja ekonomi permintaan dan sisi penawaran, sedangkan sektor responsif adalah sektor yang mendukung kinerja ekonomi dari sisi permintaan only.The sektor sensitif adalah sektor yang mendukung kinerja ekonomi dari sisi penawaran dan berkembang sektor didefinisikan sebagai sektor yang belum kontribusi optimal dari kedua permintaan dan penawaran samping. Metode penelitian adalah inputoutput. Database berdasarkan data tahun 2005, dan kemudian menggunakan teknik RAS untuk meng-upgrade data menjadi data 2011. Hasil analisis menunjukkan bahwa sektor-sektor strategis dari setiap daerah umumnya makanan dan minuman sektor, kecuali untuk wilayah Kalimantan Timur yang memiliki petrokimia sebagai sektor strategis. sektor strategis menjadi sektor kunci untuk mengurangi kesenjangan antar daerah karena dapat menghasilkan siklus ekonomi, konektivitas antar sektor dan sebagai yang paling terhubung. Oleh karena itu, kinerja sektor ini harus ditingkatkan untuk memungkinkan mereka untuk meningkatkan output dan kinerja ekonomi juga.
\end{abstract}

Kata kunci: Analisys, Sektor, Strategis

\section{STRATEGIC SECTOR ANALYSIS OF THE ISLAND OF SULAWESI, EAST JAVA AND EAST KALIMANTAN}

ABSTRAK. This study analyzes the strategic sector, the responsive sector, the sensitif sector and undeveloped sector as well in the Other Sulawesi regions (North Sulawesi, Central Sulawesi, Southeast Sulawesi and Gorontalo), the South Sulawesi (including the West Sulawesi), the East Java and East Kalimantan. Selection of the locationbased on the intensity of trade interaction among the regions andthe existing of economic characteristicof each region. The strategic sektor is a sector that support economic performance from the demand and supply side, while the responsive sector is a sector that support economic performance from demand side only. The sensitive sector is a sector that support economic performace from supply side and the undeveloped sector is defined as the sector that have not contributed optimally from both demand and supply side. Research method is an interregional inputoutput. The base data is data of 2005, then employing RAS technique to upgrade the data to be 2011 data. Results of analysis show that the strategic sector from each region is generally the food and beverages sector, except for the East Kalimantan region that has petrochemical as the strategic sector. The strategic sector become a key sector to decrease gap among regions because it can generate economic cycle, connectivity among sector and as the most connected sectors. Therefore, the performance of the sector should be enhanced to enable them to increase output and economic performance as well.

Key words: Analisys, Sector, Strategic

\section{PENDAHULUAN}

Hingga saat ini, pembangunan wilayah terus menunjukkan asimetrik ekonomi. Hal tersebut tercermin pada konsentrasi ekonomi masih dominan di wilayah Jawa. Penelitian ini menawarkan ide pendekatan spasial dan mengoptimalkan potensi strategi ekonomi wilayah untuk mengatasi persoalan asimetrik ekonomi. Ide dasar untuk mengoptimalkan pendekatan spasial dengan memperhatikan beberapa faktor yang menghambat interaksi yaitu seperti imperfect factor mobility, imperfect factor divisibility dan imperfect mobility of goods and services (Hoover dan Giarratni, 1999). Berbagai kendala tersebut disebabkan oleh jaringan infrastruktur tidak terkoneksi dengan baik, kekhasan dan produk. Kekhasan yang dimiliki oleh wilayah seperti potensi pertambangan batu bara, bahan baku semen dan kehutanan hanya bisa diolah pada lokasi spesifik dimana potensi tersebut berada. Dengan demikian, Pertambangan batu bara dan industri semen hanya bisa diolah dan diproduksi dimana potensi tersebut berada. Situasi inilah yang mendorong diperlukannya interkasi ekonomi (spasial) untuk mengoptimalkan potensi wilayah atau potensi strategis disuatu wilayah. Optimalisasi potensi strategis wilayah diharapkan menjadi jalan keluar dalam mengurai asimetrik ekonomi antar wilayah.

Sayangnya beberapa potensi strategis di wilayah Sulawesi Selatan, Kalimantan Timur dan Sulawesi Lainnya seperti pertambangan batu bara, industri semen dan pertanian belum mampu mendorong wilayah menjadi mandiri karena (1) sebagian besar pengolahan potensi tersebut lebih banyak bergantung pada modal dan sumberdaya dari luar wilayah (luar negeri) dan (2) lemahnya teknologi. Akibatnnya, perekonomian 
suatu wilayah cenderung sangat bergantung pada pengaruh wilayah atau negara lain (stimulus response) dalam menggerakkan perekonomiannya (Hannon dan Ruth1994) dan (Saefulhakim 2008). Dalam jangka panjang, situasi ini akan memicu dan merangsang terjadinya pengurasan sumberdaya (backwash effect) sehingga pembangunan ekonomi menjadi tidak simetrik (Myrdal 1968).

Kondisi perekonomian saat ini masih menunjukkan disparitas ekonomi antar Jawa Timur dengan Kalimantan Timur, Sulawesi Selatan dan Sulawesi Lain. Output perekonomian Jawa Timur mencapai Rp. 419.428 milyar pada Tahun 2013 sedangkan Sulawesi Selatan hanya mencapai Rp. 64.284,43 milyar. Jauh lebih rendah jika dibandingkan dengan Sulawesi Tenggara, Sulawesi Tengah, Sulawesi Utara dan Gorontalo. Adapun output perekonomian Kalimantan Timur yang tinggi lebih banyak dipengaruhi oleh aktifitas pertambangan. Secara rinci tersaji pada Tabel 1 kondisi output perekonomian wilayah di Sulawesi Selatan, Sulawesi Lain (terdiri Sulawesi Utara, Sulawesi Tengah, Sulawesi Tenggara dan Gorontalo), Kalimantan Timur dan Jawa Timur yang mencerminkan asimetrik ekonomi .

Tabel 1. Nilai PDRB konstan (dalam ratus milyar) di masingmasing provinsi periode Tahun 2011-2013

\begin{tabular}{|c|c|c|c|c|}
\hline No & Wilayah & 2011 & 2012 & 2013 \\
\hline 1 & $\begin{array}{l}\text { Sulawesi } \\
\text { Selatan }\end{array}$ & $55.093,74$ & $59.718,50$ & $64.284,43$ \\
\hline 2 & $\begin{array}{l}\text { Sulawesi } \\
\text { Tenggara }\end{array}$ & $12.698,12$ & $14.020,35$ & $15.040,86$ \\
\hline 3 & $\begin{array}{l}\text { Sulawesi } \\
\text { Utara }\end{array}$ & $19.735,47$ & $21.286,58$ & $22.872,16$ \\
\hline 4 & $\begin{array}{l}\text { Sulawesi } \\
\text { Tengah }\end{array}$ & $19.230,92$ & $21.007,97$ & $22.979,40$ \\
\hline 5 & Gorontalo & $3.141,45$ & $3.383,82$ & 3.646 .55 \\
\hline 6 & $\begin{array}{l}\text { Kalimantan } \\
\text { Timur }\end{array}$ & $115.489,85$ & $120.085,76$ & $121.990,49$ \\
\hline 7 & Jawa Timur & $366.983,28$ & $393.662,85$ & $419.428,45$ \\
\hline
\end{tabular}

Sumber. BPS, 2014

Tantangan dalam usaha mempercepat proses pembangunan antar wilayah adalah dengan memperhatikan dan memahami indonesia's growth pole, belum jelasnya leading sectors (the most connectivity) setiap provinsi, backward regions, fenomena debottlenecking infrastructure dan masalah finansial (Kuncoro, 2013). Kendala terbesar yang menyebabkan wilayah lain sulit mendekatan kinerja ekonomi wilayah Jawa Timur karena jauhnya manfaat dari aglomerasi yang cukup kuat di Jawa dibandingkan wilayah lain (Amita dan Kameron 2004). Faktor lain yang menyebabkan Jawa Timur (dan Jawa) lebih berkembang karena dipengaruhi oleh 2 (dua) hal yaitu (1) karena adanya ketidaksamaan penyebaran penduduk, pendapatan, dalam arti luas sumberdaya dan (2) adanya kegiatan ekonomi skala besar pada wilayah tertentu (Isard, 1951).
Disisi lain Pengolahan (hilirisasi) kekhasan atau potensi strategis dalam suatu wilayah mutlak dilakukan untuk menciptakan keragaman ekonomi sehingga berkorelasi pada peningkatan intensitas dan interaksi ekonomi wilayah. Trinh et al (2000) mengemukakan bahwa aliran barang yang beragam dari wilayah asal ke wilayah lain sangat mempengaruhi perkembangan ekonomi wilayah asal. Pengembangan sektor dan potensi strategis tidak hanya mendorong perubahan struktur ekonomi dari sisi supply dan demand (CheneryWatanabe, 1958), tetapi akan memberikan dampak terhadap output perekonomian wilayah (Daryanto and Hafizrianda, 2010). Pengembangan sektor strategis akan (1) mengurangi disparitas ekonomi antar wilayah dan mendorong sektor-sektor lain terpacu dan lebih produktif, (2) menahan laju migrasi penduduk (terutama sumberdaya manusia terampil) dan (3) meningkatan nilai tambah ekonomi wilayah. Sektor strategis yang tercermin pada kekuatan External Backward Linkage (EBL) dan External Forward Linkage (EFL) (Hasegawa, 2012) diharapkan mampu mempengaruhi output perekonomian dan responsif terhadap perubahan permintaan. Penerapan input-output interregional (IRIO) sangat relevan dalan mengembangkan sektor strategis wilayah.

Studi menggunakan IO analisis untuk menginvestigasi peran sektor tenaga listrik (hydroelctric, fossil-fuels, nuclear dan non-utility) terhadap perekonomian korea pada periode waktu 1985-1998. Hasilnya menujukkan bahwa tenaga listrik non-utility memberikan pasokan investasi yang paling besar dalam untuk menghasilkan output sektor lain. Sektor keuangan dan asuransi, real estate dan jasa perusahaan, adalah sektor yang mendapatkan pasokan paling tinggi dari sektor energi listrik. Sektor logam, bahan kimia, sektor tekstil dan pakaian adalah sektor yang masih kurang mendapatkan pasokan dari sektor energi listrik. Energi listrik yang berasal dari fosil dan tenaga nuklir memberikan pasokan yang paling besar terhadap sektor industri dibandingkan pasokan energi listrik tenaga hydro (Hana, et.al 2003).

Penelitian mengestimasi dampak dan kontribusi sektor kelautan terhadap perekonomian regional dan nasional di Irlandia. Sektor perikanan tidak hanya memberikan efek langsung ttehadap perekonomian tetapi juga memberikan pengaruh inter sektoral. Sektor pengolahan perikanan, jasa transportasi air, sektor jasa penelitian dan pengembangan dan sektor jasa pengelolahan limbah merupakan sektor yang strategis karena memiliki nilai backward linkage yang tinggi. Sektor jasa transportasi air sektor ketujuh tertinggi yang memiliki nilai forward linkage. Sektor transportasi air merupakan sub sektor kelautan yang paling besar memiliki nilai forward linkage dibandingkan dengan sub sektor kelautan lainnya. Irlandia merupakan negara kepulauan yang terbuka. Sektor transportasi air 
memainkan peran penting terhadap arus barang ekspor dan impor. Jasa transportasi merupakan bagian penting dalam intermediate services terhadap proses poroduksi dengan sektor manufaktur. Nilai forward linkage subsektor kelautan lainnya mencerminkan produk barang jasa sektor banyak digunakan sebagai konsumsi akhir (Morrissey dan Donoghue, 2012).

Budidaya perikanan darat menjadi solusi untuk mengurangi eksploitasi ikan laut yang berlebihan. Budidaya ikan darat juga menjadi solusi untuk menjaga ketahanan pangan. Studi ini menganalisis dampak backward lingkage dan forward lingkage sektor perikanan tangkap dan budidaya perikanan dengan menggunakan metode IO. Data yang digunakan adalah data IO Korea tahun 1995-2010. Hasilnya menunjukkan nilai forward linkage sektor perikanan kurang 1 mengindikasikan bahwa ketika permintaan akhir naik, respon sektor perikanan lebih kecil dari pada sektor lain. Kedua, backward linkage sektor perikanan tangkap adalah kurang dari 1, mengindikasikan bahwa sektor perikanan tangkap memiliki dampak perekonomian nasional kecil dibanding sektor lain. Sebaliknya sektor budidaya perikanan memiliki dampak backward linkage yang lebih tinggi dari pada sektor lain (sektor perikanan tangkap). Dengan kata lain sektor budidaya perikanan lebih kuat mendorong perekonomian dari pada sektor perikanan tangkap. Sektor budidaya perikanan juga dapat dikatakan sebagai sektor primer yang lebih kuat mendukung sektor industri daripada sektor perikanan tangkap (Kyulee dan Yoo, 2013).

Stilwell, et.al (2000) menganalisis dampak nilai tambah sektor pertambangan emas dan batu bara terhadap tenaga kerja dan produksi. Hasilnya dampak perubahan marginal produksi dan tenaga kerja di sektor pertambangan tidak signifikan berbeda dengan sebagian besar sektor di Afrika Selatan. Sektor pertambangan ada yang terkait dengan sektor ekonomi lainnya. Kebijakan yang disarankan dari hasil penelitian adalah aktifitas pertambangan di Afrika Selatan akan meningkat pendapatan dan tenaga kerja jika ekspor ditingkatkan atau kebijakan memperkuat keterkaitan antar sektor pertambangan dengan berbagai sektor ekonomi di Afrika Selatan.

Chang, et.al (2014) sektor pelabuhan memainkan peranan dalam ekonomi Negara Afrika Selatan. Efek backward linkage dan forward linkage, efek perubahan harga dan efek tenaga kerja diestimasi untuk menentukan dampak sektor pelabuhan. Hasilnya efek forward linkage sektor pelabuhan sebesar 0,97 dan efek backward linkage sebesar 0,48, mengindikasikan bahwa sektor pelabuhan tidak banyak menggunakan sektor lain dalam memproduksi kegiatan, namun sektor pelabuhan relatif lebih banyak digunakan oleh industri lain karena nila forward efek yang tinggi.

\section{METODE}

Metode yang digunakan adalah non-survei atau pendekatan secara tidak langsung. Jenis data yang digunakan adalah data Input-Output Inter Regional (IRIO) Tahun 2005 terdiri dari 35 sektor. Data IRIO diRAS (upgrade) ke Tahun 2011 karena persediaan data hanya Tahun 2005. Metode RAS (Miller dan Blair, 2009) dilakukan agar diperoleh nilai koefisien produksi yang tepat (Isard, 1951). Model IRIO merekam interaksi antar pelaku dan wilayah aktifitas ekonomi dikembangkan oleh Wassily Leontif Tahun 1930-an (Miller dan Blair, 2009). Lokasi Penelitian di Sulawesi Lain (Sulawesi Tenggara, Sulawesi Tengah, Sulawesi Utara dan Gorontalo), Sulawesi Selatan (termasuk Sulawesi Barat), Jawa Timur dan Kalimantan Timur. Tahap awal menganalisis interaksi perdagangan dan arus barang antar wilayah dari sisi outflow dan inflow. Formulasi vang digunakan;

$X_{1}=z_{11}+z_{12}+z_{13} \cdots+z_{1 n}+Y_{1}$

$X_{2}=z_{21}+z_{22}+z_{23} \cdots+z_{2 n}+Y_{2}$

$X_{n}=z_{n 1}+z_{n 2}+z_{n 3} \cdots+z_{n n}+Y_{n}$

Persamaan di atas dapat di sederhanakan menjadi (2);

$\sum_{i=1}^{35} Z_{i j}+Y_{j}=X_{j}$

Selanjutnya menentukan nilai koefisien input teknik dengan menterjemahkan jumlah input sektor i yang dibutuhkan untuk menghasilkan satu unit output sektor j. Formula matematika ;

$a_{i j}=\frac{x_{i j}}{x_{J}}$

$A=\left[\begin{array}{cccc}a_{11} & a_{12} & \ldots & a_{1 n} \\ a_{21} & a_{22} & \cdots & a_{2 n} \\ \vdots & \vdots & \ddots & \vdots \\ a_{n 1} & a_{n 2} & \cdots & a_{n m}\end{array}\right]$ input atau teknologi

Dengan menggunakan operasi_matematika persamaan (3) dapat di rubah menjadi $Z_{i j}=a_{i j} X_{j}$, ehingga persamaan tersebut dapat ditulis dengan ;

$X_{1}=a_{11} X_{1}+a_{12} X_{2}+a_{13} X_{3}+\cdots+a_{1 n} X_{n}+Y_{1}(5)$ $\left(1-a_{11}\right) X_{1}-a_{12} X_{2}-a_{13} X_{3}-\cdots-a_{1 n} X_{n}=Y_{1}$..

(6)

Persamaa (7) dapat disederhanakan dengan menggunakan notasi matriks ;

$(1-A) X=Y$

$X=(I-A)^{-1} \dddot{Y}$

Dimana, I adalah matrik identitas yang berukuran $\mathrm{n} \times \mathrm{n}, \mathrm{A}$ adalah matrik koefisien input sedangkan $\mathrm{X}$ dan $\mathrm{Y}$ adalah vektor kolom matrik output dari persamaan akhir. Matriks Leontif adalah matriks kunci untuk mengetahui berbagai peramalan model input output, mengestimasi keterkaitan sektor wilayah dan antar wilayah melalui pendekatan backward lingkage dan forward lingkage (Daryanto and Hafizrianda, 2010). Metode yang 
digunakan oleh Chenery-Watanabe (1958) untuk mengestimasi keterkaitan antar sektor adalah backward dan forward lingkage. Pijakan dasar dari estimasi tersebut diperoleh dari model Leontif dimana backward lingkage melihat sisi permintaan (demand driven) dan forward lingkage melihat sisi penawaran (supply driven). Formula keterkaiatan langsung dan tidak langsung kebelakang dan ke depan pada persamaan (9), dimana BL adalah keterkaitan langsung dan tidak langsung kebelakang dan FL adalah keterkaitan langsung dan tidak langsung kedepan.

$B L_{j}^{R}=\sum_{j=1}^{n} g_{i j}$ dan $\mathbb{R l}_{i}^{i}=\sum_{i=1}^{n} g_{i j}$

Formula yang digunakan untuk mengukur sektor strategis adalah (1) mengestimasi daya sebar kebelakang dan (2) kepekaan terhadap permintaan akhir, formulanya ;

$$
\begin{aligned}
& B L=\frac{\Sigma_{i} g_{i j}}{\frac{1}{n} \Sigma_{i} \Sigma_{j} g_{i j}} . \\
& F L=\frac{\Sigma_{j} g_{i j}}{\frac{1}{n} \Sigma_{i} \Sigma_{j} g_{i j}} .
\end{aligned}
$$

Sektor yang strategis adalah sektor yang memiliki nilai rata-rata daya sebar dan kepekaan lebih besar 1 . Sektor yang memiliki nilai rata-rata daya sebar lebih besar 1 tetapi nilai rata-rata kepekaan lebih kecil dari 1 disebut sebagai sektor yang responsif atau sektor tersebut mampu mendorong perekonomian secara total. Sektor yang memiliki nilai rata-rata daya sebar kecil dari 1 tetapi nilai rata-rata kepekaan lebih besar 1 disebut sektor sensitif atau sektor yang sensitif jika permintaan akhir naik. Sektor yang belum berkembang adalah sektor yang memiliki nilai rata-rata daya sebar dan kepekaan kurang dari 1 .

\section{HASIL DAN PEMBAHASAN}

Hasil analisis menunjukkan bahwa sektor yang sensitif di Sulawesi Lain terhadap perekonomian adalah sektor perdagangan, sektor servis lain, sektor perkebunan, sektor pertambangan batu bara dan bahan galian dan sektor perikanan. Sensitifitas sektor disebabkan perubahan permintaan akhir agregat meningkatkan output sektor tersebut lebih besar 1. Sektor perkebunan dan perikanan merupakan salah satu sektor basis di Sulawesi Lain. Sensitifitas sektor tersebut karena banyak dipakai oleh sektor lain, banyak diekspor domestik dan jumlahnya relatif banyak.

Pengaruh sensitifitas pada sektor pertambangan didorong oleh tingginya volume produksi pertambang nikel di Sulawesi Tenggara, komoditas kakao di Sulawesi Tengah dan komoditas perikanan di Sulawesi Utara. Ketiga komoditas tersebut menguasai pangsa ekspor masing -masing wilayah sehingga secara langsung berdampak pada kinerja ekonomi pada saat permintaan akhir meningkat. Sayangnya, tingginya volume ekspor tidak disertai dengan pengembangan industri pengolahan dan hilirisasi. Akibatnya dampak ekspor komoditas tersebut tidak banyak memberikan income multipication terhadap sektor lain. Sejatinya sektor pertambangan, perkebunan dan perikanan di Sulawesi Lain tidak hanya menjadi sektor yang sensitif terhadap kinerja ekonomi tetapi dapat menjadi sektor strategis serta the leading sector (the most connectivity sector). Peluang komoditas tersebut menjadi the leading sectors sangat mungkin tercapai karena luasan tanam areal komoditas perkebunan kakao dan perkebunan lainnya sangat besar terlebih lagi komoditas perkebunan sebagian besar berorientasi ekspor. Demikian halnya dengan sektor perikanan dapat menjadi the leading sectors karena didukung dengan ketersediaan sumberdaya perikanan melimpah dalam jumlah besar di laut Sulawesi. Usaha untuk memperkuat sektor perikanan masih terkonsentrasi di Pelabuhan Bitung Sulawesi Utara. Industri pengolahan yang sudah ada di Bitung baru pada tahap pengemasan (kaleng ikan), sementara industri turunan jenis lain untuk komoditas udang dan perikanan laut masih sangat terbatas. Belum ada upaya pemerintah yang signifikan untuk meningkatkan investasi dibidang hilir untuk mendorong sektor tersebut lebih strategis. Fakta tersebut tercermin pada rendahnya insentif dari segi kebijakan, perundang-undangan, biaya riset industri dan alokasi anggaran hilirisasi menuju hulu masih rendah.

Sektor yang responsif terhadap perekonomian adalah sektor peternakan, industri kelapa sawit, pengolahan ikan, industri tekstil, indutri barang kayu, industri pulp dan kertas, industri karet, industri dasar besi dan baja, industri barang logam, industri alat transportasi, industri lain, sektor listrik, gas, dan air dan sektor transportasi udara. Sektor yang responsif mencerminkan sektor tersebut mampu meningkatkan output perekonomian ketika permintaan akhir naik. Umumnya sektor yang responsif adalah sektor industri.

Sektor yang responsif sudah menunjukkan adanya connectivity dengan sektor lain sehingga menciptakan multipication income, namun cakupannya masih terbatas karena (1) jumlah dan skala produksi yang masih kecil dan (2) nilainya masih rendah. Skala dan nilai produksi yang rendah karena dipengaruhi oleh inovasi dan teknologi yang masih rendah, sumberdaya manusia yang rendah dan modal dan daya saing masih rendah.

Sebagai ilustrasi, connectivity industri karet menunjukkan bahwa kinerja ekonomi industri karet memiliki connectivity dengan perkebunan karet, tenaga kerja, perdagangan dan sektor lain. Hal tersebut menunjukkan ketika output perekonomian industri karet meningkat akan berpengaruh terhadap sektor lain. Situasi ini menunjukkan bahwa industri karet memiliki efek pengganda dan multipication pendapatan dengan sektor lain. Umumnya sektor yang responsif adalah sektor industri karena sektor tersebut membutuhkan 
beragam input dari sektor lain. Semakin beragam input yang digunakan semakin besar connectivity antas sektor, namun belum terkategori sebagai sektor strategis karena masih terkendala pada skala ekonomi, teknologi dan kapasitas produksi.

Berbagai kendala memerlukan injeksi kebijakan dari sisi investasi sumberdaya manusia, inovasi teknologi, penelitian terkait industri dan laboratorium moderen dalam rangka mewujudkan hilirisasi industri. Sektor yang responsif sulit berkembang menjadi sektor strategis bila tidak ada injeksi kebijakan dan inovasi. Sektor tidak mampu berdaya saing dan diterima dipasar internasional. Oleh karena itu diperlukan hilirisasi industri untuk menciptakan skala produksi dan ekonomi dan connectivity antar sektor sehingga mewujudkan industri menjadi sektor strategis.

Sektor yang paling strategis di Sulawesi Lain adalah industri makanan dan minuman, sektor transportasi darat dan sektor bangunan. Sektor tersebut banyak digunakan oleh sektor lain dan banyak menggunakan sektor lain atau sektor tersebut responsif dan sensitif terhadap kinerja ekonomi. Industri makanan dan minuman seringkali menjadi garda terdepan dalam mendorong pertumbuhan ekonomi karena memiliki keeratan dengan kebutuhan dasar rumah tangga. Disisi lain industri makanan dan minuman memiliki connectivity dengan beragam sektor karena membutuhkan beragam input dari sektor pertanian, perkebunan, peternakan, transportasi dan sektor lainnya. Hal ini tidak hanya terjadi pada industri makanan dan minuman tetapi dialami juga oleh sektor bangunan dan transportasi darat di Sulawesi Lain.

Sektor bangunan menjadi strategis karena mengikuti program dan visi pemerintah dalam mendorong konektifitas pembangunan wilayah dan nasional. Peran strategis sektor bangunan adalah menghubungkan (1) aliran komoditas hasil pertanian dan komoditas industri, (2) aliran lintas sumberdaya manusia ke daerah kurang maju (hinterland) dalam rangka mendorong spillover pembangunan manusia, (3) aliran mobilitas teknologi, jasa dan komunikasi dan (4) menciptakan efisiensi dan efektifitas konektifitas antar intra dan ekstra wilayah. Peran strategis sektor transportasi darat karena transportasi darat menjadi alat utama untuk meningkatkan mobilitas angkutan hasil produksi perkebunan, pengiriman barang dan penumpang antar wilayah di Sulawesi. Peran strategis sektor bangunan dan transportasi memperkuat dugaan kedua sektor tersebut saling berkorelasi mendorong kinerja ekonomi. Namun ada beberapa sektor yang diharapkan menjadi sektor strategis tetapi belum nampak peranannya yaitu sektor industri pengolahan ikan dan industri pengolahan kayu. Pengembangan sektor strategis mendorong daya saing ekonomi wilayah, mengurangi disparitas ekonomi dan mengungkit sektor lain menjadi lebih berkembang. Secara rinci pengelompokan sektor di Sulawesi Lain tersaji pada Gambar 1.

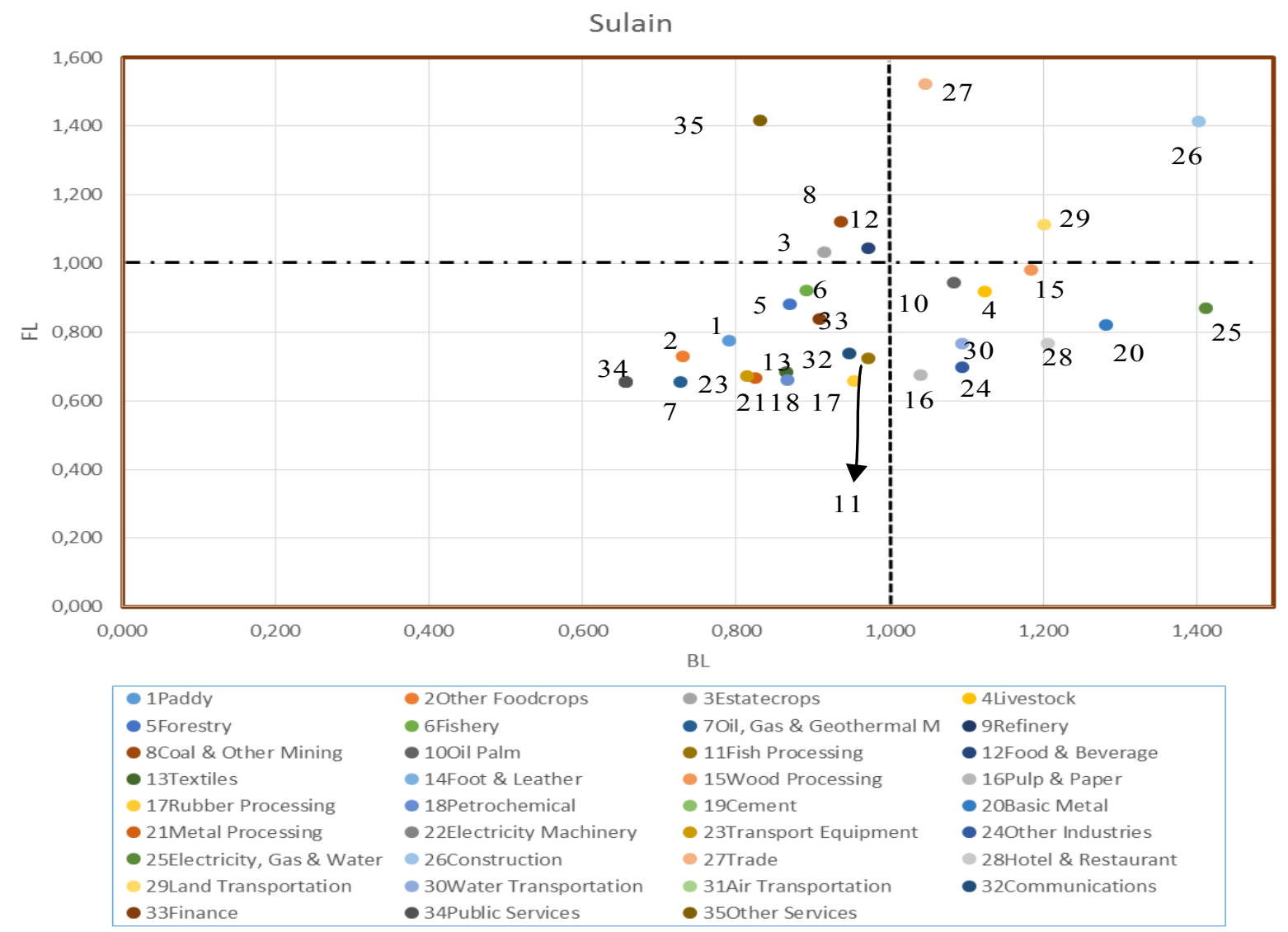

Gambar 1. pengelompokan sektor di Sulawesi Lain 
Sektor yang sensitif di Sulawesi Selatan adalah sektor padi, sektor perkebunan dan sektor perikanan. Ketiga sektor tersebut merupakan sektor basis di Sulawesi Selatan. Wilayah Sulawesi Selatan ditetapkan sebagai lumbung pangan dan perikanan wilayah Indonesia Timur dan penghasil coklat (kakao) terbesar di Indonesia. Sensitifitas sektor basis tersebut karena komoditas tersebut banyak digunakan oleh sektor lain di daerah asal dan daerah lain, kelebihan dari sisi supply dan banyak diekspor. Komoditas kakao di Sulawesi Selatan merupakan komoditas terbesar yang diekspor ke luar negeri. Sayangnya, komoditas tersebut belum terkategori dalam sektor strategis karena kurang memiliki connectivity dengan sektor lain. Kurangnya connectivity komoditas kakao dengan sektor lain mencerminkan kinerja ekonomi komoditas tidak banyak memberikan multipication pendapatan dan efek pengganda dengan sektor lain dan tenaga kerja. Hal ini sekaligus menyiratkan bahwa ekspor kakao hanya berbentuk bahan baku sehingga menghasilkan nilai tambah rendah. Komoditas perikanan dan padi mengalami hal yang sama dengan komoditas kakao di Sulawesi Selatan.

Sektor yang responsif di Sulawesi Selatan adalah sektor peternakan, industri pengolahan ikan, industri tekstil, industri pulp dan kertas, industri karet, petrokimia, industri semen, industri baja, sektor listrik, gas dan air, sektor hotel dan restoran, sektor transportasi udara dan transportasi darat. Hasil yang menarik pada kinerja sektor yang responsif adalah masuknya sektor peternakan sebagai sektor yang responsif. Hasil tersebut menunjukkan sektor peternakan memiliki conectivity dengan beragam sektor meskipun output dari sisi supply cenderung rendah. Sektor peternakan dinilai mampu mempengaruhi kinerja sektor lain tetapi masih memiliki kendala produktifitas dan produksi serta jumlah ternak. Hal ini terjadi karena budidaya dan pengembangan ternak di Sulawesi Selatan masih bersifat tradisional, terbatasnya sumberdaya manusia, terbatasnya teknologi dan budidaya ternak masih skala kecil. Sektor yang responsif lainnya mengalami kasus yang relatif sama dengan sektor peternakan.

Sektor yang sangat strategis di Sulawesi Selatan adalah Sektor industri makanan dan minuman, sektor bangunan dan sektor perdagangan. Ketiga sektor tersebut tidak hanya sensitif pada setiap perubahan permintaan akhir agregat tetapi memiliki kekuatan pendorong output perekonomian. Sulawesi Selatan sangat ditopang oleh industri makanan dan minuman karena sebagian bahan baku seperti padi, perkebunan coklat dan kopi, peternakan merupakan sektor basis ekonomi daerah. Sulawesi Selatan menjadi sentra perkebunan coklat, kopi dan padi di wilayah timur indonesia. Hanya $7 \%$ dan 6,2\% input antara dari daerah lain (inflow) serta $9,4 \%$ dan $0,89 \%$ (dari total impor) input yang berasal dari impor luar negeri pada Tahun 2005 dan 2011 (Hasil IRIO). Kebutuhan input antara dari daerah lain dan internasional terus menurun sehingga mendorong sektor yang memiliki connectivity semakin berkembang di Sulawesi Selatan.

Sektor perdagangan yang strategis di Sulawesi Selatan semakin memperkuat posisinya sebagai simpul ekonomi di kawasan Timur Indonesia. Sulawesi Selatan memiliki pelabuhan primer sekaligus sebagai pelabuhan alternatif internasional yang terhubung dengan jalur laut primer nasional. Sektor perdagangan di Sulawesi Selatan berada pada posisi strategis dikarenakan Sulawesi Selatan berada pada posisi "hub" terhadap wilayah lain. Posisi "hub" di Sulawesi Selatan didukung dengan kemampuan wilayah Sulawesi Selatan dalam menghasilkan berbagai produk untuk memenuhi permintaan akhir di wilayah lain di Kawasan Timur Indonesia. Berbagai produk yang diperdagangkan di Kawasan Timur Indonesia diantaranya adalah sektor padi, tanaman pangan, industri makanan dan minuman, industri semen dan industri lainnya. Faktor lain yang mendukung sektor perdagangan adalah budaya sebagian besar etnis di Sulawesi Selatan adalah budaya dagang dan perantau (masompa).

Peran sektor bangunan di Sulawesi Selatah tercermin pada pembangunan infrastruktur jalan, perumahan dan industri dan pusat pertumbuhan ekonomi. Pembangunan jalan sekaligus memperkuat konektifitas antar pusat pertumbuhan dan jalur perdagangan melalui laut. Sekitar $11,7 \%$ dan $14,3 \%$ dari daerah lain (inflow) serta $16,5 \%$ dan $26,5 \%$ terhadap total impor yang digunakan sebagai input antara. Pembangunan infrastruktur di Sulawesi Selatan belum diimbangi dengan kemampuan daerah untuk memenuhi secara mandiri input antara sehingga memerlukan pasokan dari wilayah lain dan impor. Persedian input antara untuk mendukung infrastruktur sudah selayaknya dipertimbangan untuk memperkuat konektifitas pembangunan antar wilayah.

Kinerja sektor yang masih rendah di Sulawesi Selatan adalah sektor bahan makanan, sektor kehutanan, sektor perminyakan, gas dan panas bumi, sektor pertambangan dan bahan galian lain, industri besi, industri alat mesin listrik, industri lain, sektor komunikasi, sektor jasa lain dan sektor pemerintahan dan pertahanan. Peran pemerintah dalam mendorong output perekonomian belum terlihat nyata (tercermin pada rendahnya nilai koefisien backward dan forward linkage).

Upaya untuk mendorong kinerja ekonomi di Sulawesi Selatan diperlukan beberapa tindakan strategis yaitu; (1) penciptaan sektor stategis baru yaitu industri perikanan karena perkinan merupakan basis ekonomi Sulawesi Selatan (2) meningkatkan rantai aktifitas sektor strategis yang terintegrasi agar output perekonomian meningkat lebih cepat, (3) mendorong inovasi teknologi sektor strategis dan sektor pendukung agar nilai tambah ekonomi meningkat, (4) meningkatkan efisiensi produksi untuk mencapai daya saing produk, (5) membangun konektifitas antar intra agar tecipta linkage ekonomi yang efisien dan efektif, (6) mendorong kerjasama 
antar daerah dalam mendukung sektor strategis masing masing wilayah dan (7) menciptakan kepastian hukum dan mengurangi ketikdapastian ekonomi. Secara rinci pengelompokan sektor di Sulawesi Selatan tersaji pada Gambar 2.

Sektor yang sensitif di Jawa Timur berbeda dengan kinerja sektor di Sulawesi Selatan dan Sulawesi Lain. Perbedaan tersebut dikarenakan karakteristik perekonomian antar wilayah tidak sama. Jawa Timur bercirikan ekonomi jasa dan industri sedangkan Sulawesi Selatan dan Sulawesi Lain berciri pertanian. Di Jawa Timur, Sektor sensitif terhadap kinerja perekonomian adalah sektor jasa lain, sektor perdagangan dan sektor pertambangan batu bara dan bahan galian. Sektor sensitif dapat tumbuh dan merangsang ekonomi dari sisi supply jika kinerja perekonomian secara keseluruhan meningkat. Sektor jasa memiliki korelasi positif dengan kinerja ekonomi di Jawa Timur. Sektor jasa tumbuh seiring dengan berkembangnya sektor industri, tumbuhnya jumlah penduduk dan pendapatan masyarakat. Laju pendapatan mendorong jasa keuangan, jasa pariwisata, jasa pendidikan, jasa kosultasi dan lain lain. Namun sektor jasa tidak memiliki conncetivity dengan sisi demand dan input. Perkembangan sektor jasa lebih banyak dipengaruhi dari sisi supply karena adanya peningkatan pendapatan dan pertumbuhan ekonomi di Jawa Timur.

Perkembangan sektor perdagangan dan pertambangan bahan galian juga didorong oleh kinerja agregat ekonomi. Sensitifitas kedua sektor tersebut tidak dipengaruhi oleh connectivity antar sektor tetapi sangat ditentukan dengan pertumbuhan ekonomi wilayah Jawa Timur. Sensitifitas sektor perdagangan dipengaruhi oleh tingginya volume perdagangan wilayah Jawa Timur dari sisi supply.

Sektor responsif di Jawa Timur adalah sektor peternakan, kehutanan, industri pengolahan ikan, industri tekstil, industri barang kayu, industri karet, industri semen, industri barang logam, industri mesin listrik dan peralatan, industri petrokimia, industri alat pengangkutan, sektor bangunan, transportasi air, transportasi udara dan sektor keuangan. Sektor yang responsif mendorong perekonomian dari sisi demand merangsang connectiviy antar berbagai sektor.

Sulsel

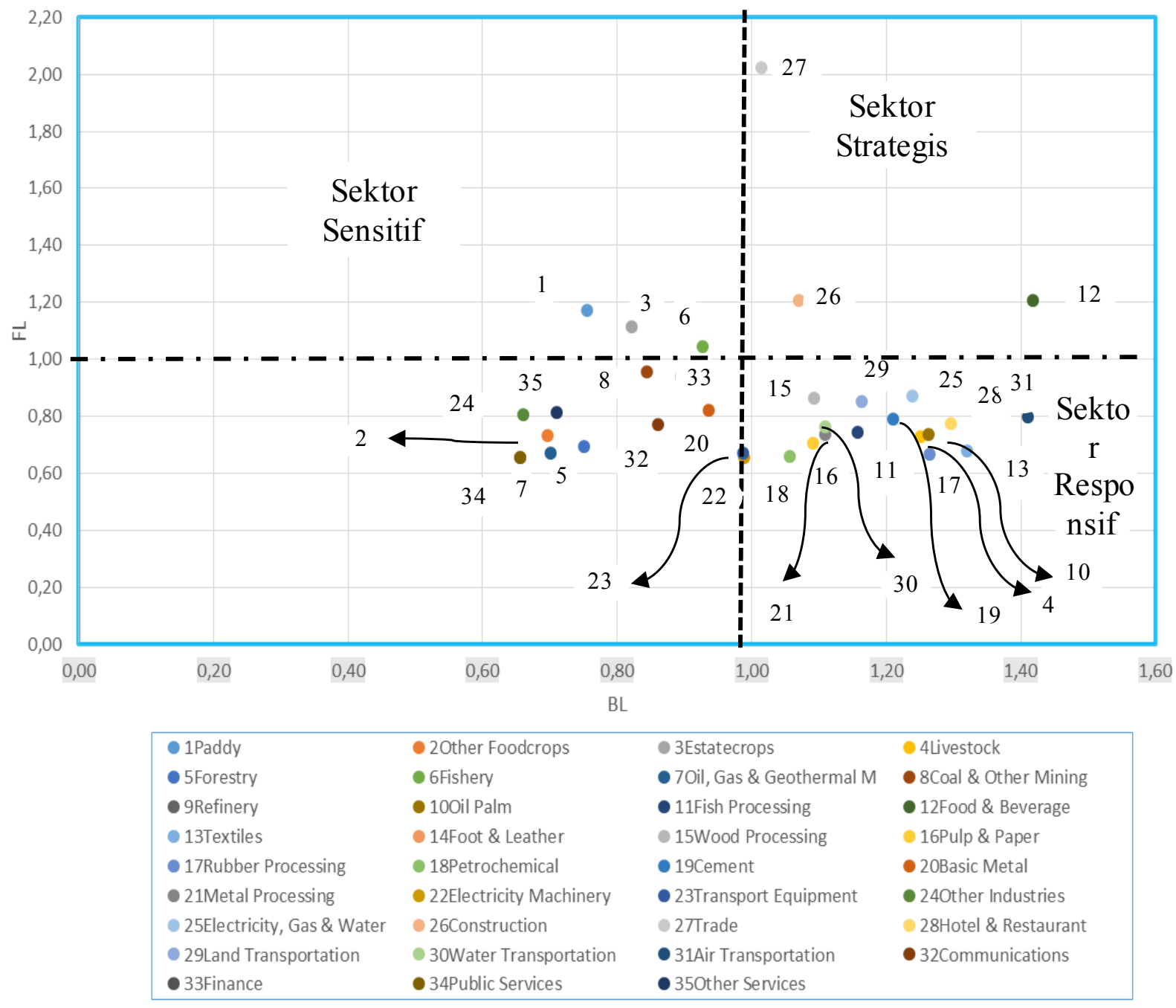

Gambar 2. pengelompokan sektor di Sulawesi Selatan 
Sektor yang paling besar memberikan pengaruh ekonomi dari sisi demand dan memiliki connectivity yang relatif lebih kompleks dengan sektor lain adalah sektor yang bergerak di bidang industri. Connectivity antar sektor tercermin pada keterkaitan input output antara industri, energi dan transportasi. Semakin tinggi input antara sektor industri dari wilayah asal semakin besar peluang meningkatkan output perekonomian. Wilayah Jawa Timur merupakan kawasan aglomerasi bermacam industri di Indonesia. Pengaruh aglomerasi mampu meningkatkan intensitas penggunaan input antara, interaksi ekonomi, penyerapan tenaga kerja dan output perekonomian. Namun berbagai industri tersebut belum masuk dalam kategori sektor strategis karena belum mampu menghasilkan output skala lebih besar dari sisi supply.

Sektor yang sangat strategis di Jawa Timur adalah sektor listrik, gas dan air, industri makanan dan minuman, sektor bangunan dan industri pulp dan kertas. Keempat sektor secara strategis mempengaruhi perekonomian dari sisi demand dan supply. Industri makanan dan minuman di Jawa Timur sangat besar jumlahnya dan beragam jenisnya. Jumlah penduduk yang besar di Jawa Timur mempengaruhi secara signifikan permintaan industri makanan dan minuman dari sisi konsumsi rumah tangga dan supply. Sektor lain yang memiliki connectivity akan berkorelasi secara positif dengan industri makanan dan minuman dalam penyedian input antara (seperti sektor padi, transportasi, perikanan dan lain lain). Hubungan tersebut selanjutnya akan menciptakan siklus input output perekonomian wilayah Jawa Timur.

Namun industri makanan memiliki kendala karena input antaraseperti susu dan tepung masih bergantung pada luar negeri. input bahan baku tersebut lebih besar bea masuknya daripada produk bahan jadi yang berbahan dasar susu dan tepung. Akibatnya industri dalam negeri berupaya melakukan efisiensi agar produk jadi dalam negeri bisa bersaing dengan produk makanan dan minuman luarnegeri. Tantangan lain adalah pemerintah meningkatkan bea masuk kemasan untuk makanan kemasan seperti biskuit. Kenaikan harga bea masuk kemasan mengakibatkan produk makanan kemasan mengalami kenaikan harga. Regulasi pemerintah untuk mengurangi tekanan biaya adalah dengan mereformasi (1) peraturan menteri keuangan No.241/PMK.011/2011 tentang Penetapan Sistem Klasifikasi Barang dan Pembebanan Tarif Bea Masuk Atas Barang Impor, (2) Peraturan Menkeu No. 19/2009 tentang penetapan Tarif Bea Masuk Atas Barang Impor Produk-Produk Tertentu dan (3) pengembangan industri penunjang sektor industri makanan dan minuman dalam rangka mengurangi ketergantungan terhadap impor (4) mengembangkan sumberdaya manusia dan teknologi untuk menunjang daya saing.

Sektor listrik, air dan gas, industri pulp dan sektor bangunan mengalami hal yang sama dengan industri makanan dan minuman yaitu Siklus input output. Kawasan aglomerasi dan faktor demografi mempengaruhi sisi supply kebutuhan energi dan air di Jawa Timur dan connectivity antar sektor. Jawa Timur memerlukan pasokan energi untuk mendukung aktifitas industri dan manufaktur. Permintaan energi dan kebutuhan bahan baku menempatkan sektor listrik menjadi sektor yang sangat strategis. Peran lain sektor listrik air dan gas adalah memasok kebutuhan penerangan dan air bersih terhadap jumlah rumah tangga yang besar. Tantangan yang dihadapi adalah input sektor listrik (mesin listrik) sebagian besar bersumber dari impor. Untuk mengurangi ketergantungan dibutuhkan inovasi teknologi dan peningkatan kualitas sumberdaya manusia. Penambahan daya melalui pembangunan berbagai jenis pembangkit tenaga listrik sangat direkomendasikan dalam menunjang industri di Jawa Timur.

Pembangunan fisik di Jawa Timur terus berlangsung dalam rangka mendorong konektifitas antar daerah. Konektifitas yang diharapkan adalah (1) menghubungkan berbagai pusat pertumbuhan ekonomi, (2) memperluas pertumbuhan ekonomi dari pusat pertumbuhan ke daerahhinterland, (3) meningkatkan efisiensi arus barang industri dan pertanian antar wilayah dan industri, (4) mempermudah arus sumberdaya manusia, modal dan teknologi ke wilayah hinterland dan (5) percepatan pembangunan wilayah hinterland.

Upaya pembangunan fisik dan regulasi pemerintah diharapkan mampu mendorong kinerja sektor di Jawa Timur yang belum optimal yaitu sektor padi, bahan makanan, perkebunan, perikanan, kehutanan, sektor minyak, gas dan panas bumi, industri alas kaki, transportasi darat, sektor komunikasi dan sektor pemerintahan dan pertahanan. Sektor yang belum berkembang tersebut disebabkan oleh (1) kinerja sektor dari sisi demand dan supply jumlahnya kecil dibandingan dengan sektor lain dan (2) rendahnya connectivity antar sektor. Secara rinci pengelompokan sektor di Jawa Timur tersaji pada Gambar 3.

Sektor yang sensitif di Kalimantan Timur adalah sektor minyak, gas dan panas bumi, sektor pertambangan batu bara dan penggalian, sektor pengilangan minyak bumi, sektor perikanan dan sektor perdagangan. Di Wilayah Kalimantan Timur, kontribusi sektor energi terhadap output perekonomian melebihi 50\% dari total output. Sayangnya, kontribusi tersebut lebih banyak dipengaruhi dari sisi produksi tetapi kurang connectivity dengan sektor lain. Sektor energi tumbuh dan berkembang tetapi belum memberikan efek pengganda dan pendapatan terhadap sektor lain. lemahnya teknologi dan inovasi menjadi penyebab sulitnya mengembangkan hilirisasi sektor energi. Sebagian besar industri pertambangan lebih mengutamakan ekploitasi tambang dalam bentuk bahan baku. Rencana pertambangan tidak dipersiapkan untuk mengembangkan hilirisasi energi. Perusahaan lebih 
Jatim

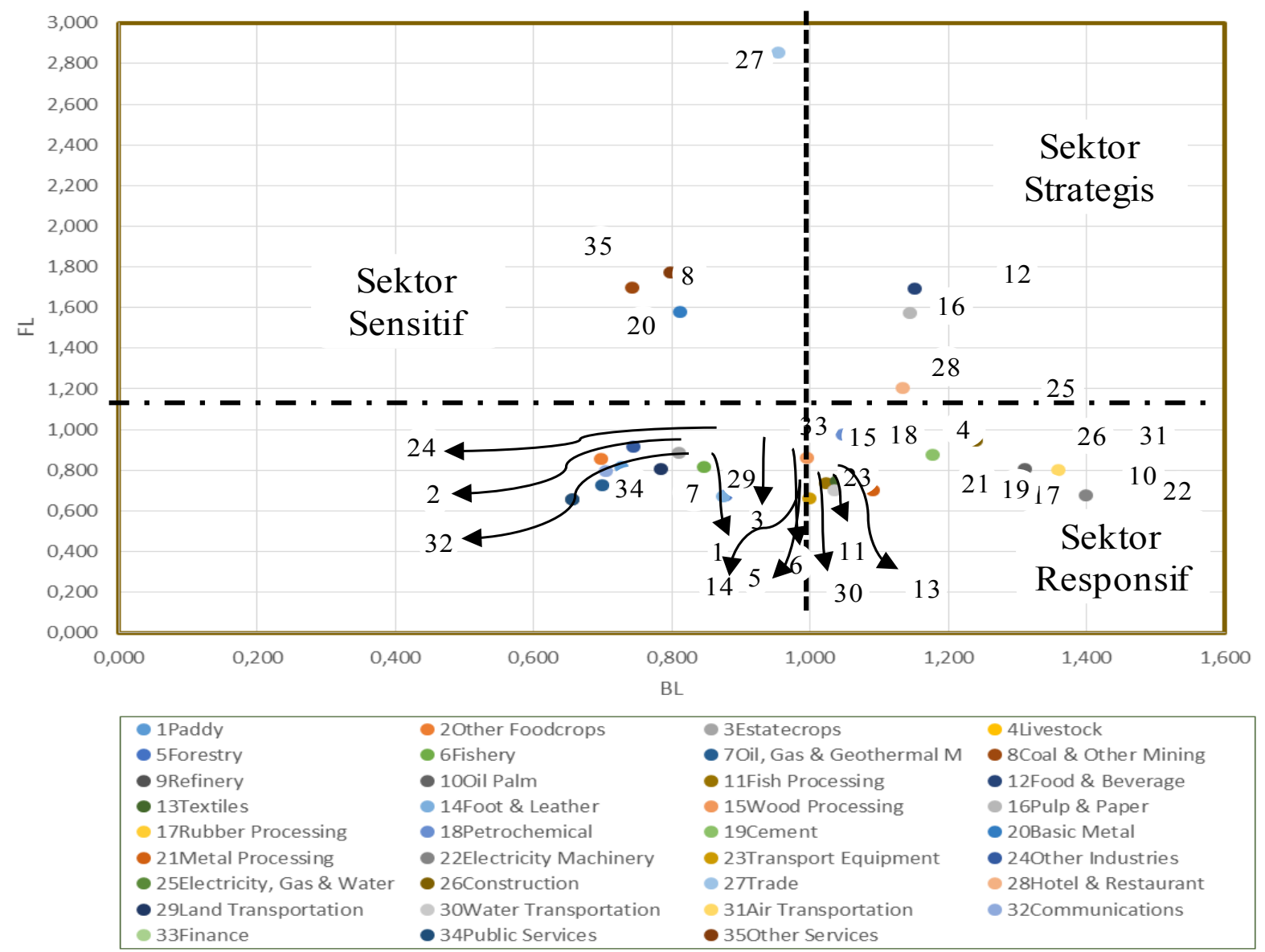

Gambar 3. Sektor strategis dan tidak strategis di Jawa Timur

menitikberatkan pemenuhan kebutuhan pasar energi berdasarkan permintaan. Akibatnya, sektor dibidang energi berkembang tetapi tidak dibarengi dengan connectivity dengan sektor lain. Sektor perikanan dan perdagangan mengalami hal yang sama seperti sektor dibidang energi di Kalimantan Timur.

Sektor yang responsif di Kalimantan Timur adalah sektor peternakan, industri makanan dan minuman, industri tekstil, industri mesin listrik, industri alat angkutan, sektor listrik, gas, dan air, sektor bangunan, hotel, dan restoran dan sektor transportasi udara. Di Sulawesi Selatan, Sulawesi Lain dan Jawa Timur, industri makanan dan minuman merupakan sektor strategis tetapi belum strategis di Kalimantan Timur. Industri makanan dan minuman memiliki connectivity dengan sektor lain tetapi masih kecil dalam skala produksi. Umumnya, industri makanan yang berkembang adalah industri makanan dan minuman skala kecil. Sektor industri lainnya mengalami hal yang sama dengan industri makanan dan minuman. Industri yang responsif hanya mampu menciptakan connectivity tetapi belum optimal pada skala produksi. Hanya sektor industri energi yang mampu menghasilkan skala produksi yang skala besar tetapi tidak memiliki connectivity dengan sektor lain. Pemerintah daerah lebih fokus pada pengembangan sektor energi tetapi belum mampu menciptakan connectivity dengan industri lainnya. Sektor energi di Kalimantan Timur lebih banyak memenuhi permintaan luar negeri dari pada memasok energi untuk kebutuhan industri. Akibatnya sektor industri mengalami disconnected dengan industri energi di Kalimantan Timur. Situasi mendorong kinerja ekonomi di Kalimantan tidak berkualitas dan salah arah. Sejatinya, Pemerintah harus meregulasi kebijakan energi melalui penggunaan energi dalam wilayah secara maksimal dengan cara mempermudah industri berkembang di wilayah tersebut. Perkembangan industri di Kalimantan Timur akan mengoptimalkan connectivity antar sektor energi dan industri di Kalimantan Timur.

Implementasi kebijakan yang perlu dipertimbangkan dalam menghadapi masalah tersebut adalah (1) mendorong pemanfaatan industri batu bara, minyak gas, industri sawit dalam wilayah melalui pembangunan industrialisasi, (2) Melakukan kerjasama dengan negara lain untuk investasi industri di dalam wilayah, (3) peningkatkan pembangunan infrastruktur untuk mendukung konektifitas antar wilayah, (4) meningkatkan rantai aktifitas ekonomi sektor basis agar menjadi sektor strategis, (5) peningkatan pengembangan teknologi dan (6) peningkatan produktifitas sektor industri sawit. Secara rinci pengelompokan sektor di Kalimantan Timur tersaji pada Gambar 4. 


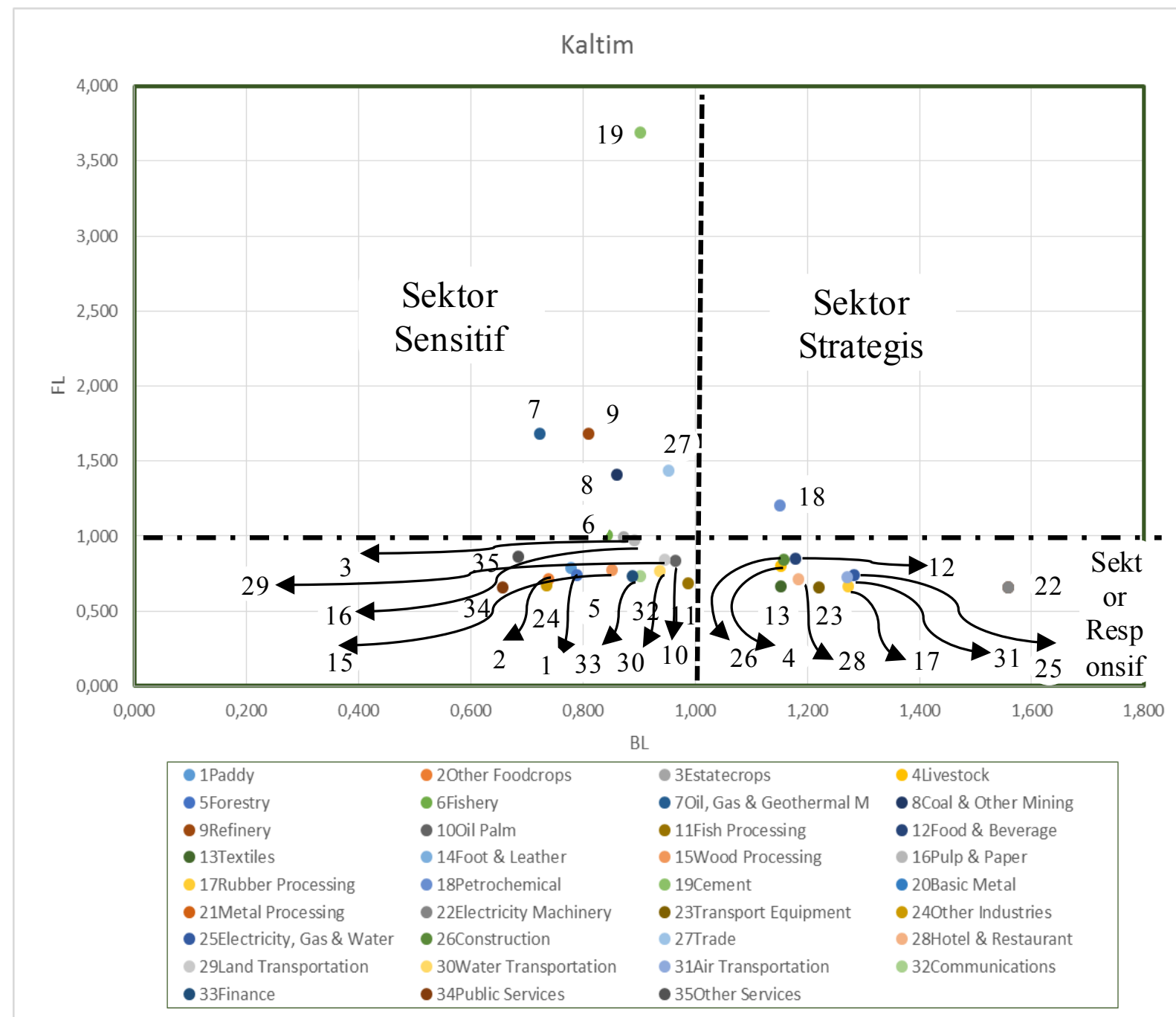

Gambar 4. Pengelompokan sektor di Kalimantan Timur

\section{SIMPULAN}

Berdasarkan hasil penelitian menunjukkan sektor strategis sangat dipengaruhi dari sisi demand dan supply. Sektor yang mampu menciptakan connectivity dengan sektor lain dan mampu menghasilkan produksi pada skala besar merupakan sektor strategis. Sektor strategis akan menciptakan siklus ekonomi secara kontiniu hingga sektor tersebut bermetamorfosa menjadi the leading sectors (the most connected sectors). Sayangnya, sektor energi di Kalimantan Timur belum mampu bermetamorfosis menjadi the leading sectors. Akibatnya sektor energi hanya mampu berdiri sendiri dan mengalami disconnected sektor.

Umumnya, sektor industri masih berada pada kategori sektor yang responsif. Hal tersebut menunjukkan bahwa industri diberbagai wilayah; (1) masih dikelelo secara tradisional dan inovasi teknologi yang rendah, (2) belum ada injeksi inovasi dan teknologi dan (3) kapasitas produksinya masih rendah. Namun, sebagian besar sektor industri di wilayah penelitian sudah mampu menciptakan connectivity dengan sektor lain, meskipun masih rendah pada skala produksi. Sektor sensitif dapat tumbuh dan merangsang ekonomi dari sisi supply jika kinerja perekonomian secara keseluruhan meningkat. Sektor menjadi sensitif karena orientasinya pada skala produksi tanpa memperhatikan connectivity antar sektor. Meskipun sektor sensitif mampu menghasilkan skala produksi yang efisien tetapi sektor tersebut mengalami disconnected dengan sektor lain. Akibatnya sektor tersebut hanya tumbuh dan berdiri sendiri tetapi tidak menciptakan siklus ekonomi secara berkelanjutan.

\section{DAFTAR PUSTAKA}

Chang, YT, Shin,SHdan PT.WooLee. 2014. Economic impact of port sectors on South African economy: An input-output analysis. Elsevier.

Chenery,HB dan T.Watanabe. 1958. International Comparasions of the Structure of Production. Econometrica, 26: 487 - 521

Daryanto,A dan Y. Hafizrianda. 2010. Model - Model Kuantitatif ; untuk perencanaan pembangunan ekonomi daerah. IPB. Bogor

Hana, SY, SH.Yoob, SJ. Kwakc. 2003. The role of the four electric power sectors in the Korean national economy:an input-output analysis. Elsevier 
Hannon,B dan M. Ruth. 1994. Dynamic Modeling. Springer-Verlag. New York.

Hoover,EM dan F.Giarratni. 1999. An Intruduction Regional Economic. West Virgina University's Regional Research Institute is distributing electronic version of the text by permission.

Hasegawa,T. 2012. External Bacward Linkage and External Forward Linkage in Asian International Input-Output Table. Presented in IIOA Conference held in Slovakia june 2012.

Isard,W. 1951. Interregional and Regional InputOutput Analysis: A Model of A SpaceEconomy. The review of Econoic and Statistic. Vol 33, 318-328.

Kuncoro,M. 2013. Economic Geography Of Indonesia: Can MP3EI Reduce Inter-Regional Inequality. South East Asia Journal of Contemporary Business, Economic and Low, Vol. 2, Issue 2.

KyuLee, M dan Yoo, SH. 2013. The role of the capture fisheries and aquaculture sectors in the Korean national economy: An inputoutput analysis. Elsevier.
Morrissey,K, C. Donoghue. 2012.The role of the marine sector in the irish national economy : An input-output analysis. Elsevier

Myrdal,G. 1968. Asian Drama:An Inquiry into the Poverty of Nations.NewYork Pantheon Books.

Saefulhakim,S. 2008. Model Pemetaan Potensi Ekonomi Untuk Perumusan Kebijakan Daerah: Konsep, Metode, Aplikasi dan Teknik Komputasi. Community an Regional Development Institute of Aqwati (CORDIA). Bogor.

Stilwell, LC, RCA. Minnitt,TD. Monson dan G. Kuhn. 2000.An input-output analysis of the impact of mining on the South African economy. Elsevier

Trinh,B, K.Kobayashi, TN.Quang, dan PN.Viet. 2000. Multi-interregional economic impact analysis based on multi-interregional input output model consisting of 7 regioans of Vietnam. Journal of Finance and Investment Analysis vol 1. no 12. International scientific Press. 